\title{
Eosinophilic Fasciitis: A Case Report and Review of the Literature
}

\author{
Eozinofilik Fasiit: Bir Olgu Sunumu ve Literatürlerin Gözden Geçirilmesi
}

\author{
Yasemin Turan ${ }^{1}$, Ömer Faruk Şendur ${ }^{1}$, Işıl Karataş-Berkit ${ }^{1}$, Hakkı Arslan ${ }^{1}$, Emel Dikicioğlu-Çetin ${ }^{2}$ \\ ${ }^{1}$ Adnan Menderes Üniversitesi Tıp Fakültesi, Fiziksel Tıp ve Rehabilitasyon Anabilim Dalı, Aydın, Turkey \\ ${ }^{2}$ Adnan Menderes Üniversitesi Tıp Fakültesi, Patoloji Anabilim Dalı, Aydın, Turkey
}

\begin{abstract}
Eosinophilic fasciitis is a rare entity characterized by peripheral eosinophilia, fasciitis and "groove sign". The characteristic features of this inflammatory disease include scleroderma-like skin indurations, predominantly on the extremities, and peripheral blood eosinophilia. Systemic organs are generally not affected. In this paper, we present the clinical characteristics of a 35-year-old male patient who could not be diagnosed for a long period and was diagnosed as eosinophilic fasciitis following muscle biopsy. We also include herein the results of our literature survey regarding this disease. (Turk J Rheumato/ 2010; 25: 208-13) Key words: Eosinophilic fasciitis, groove sign
\end{abstract}

Received: 05.11.2008

Accepted: 05.12.2008

\section{Özet}

Eozinofilik fasiit, periferik eozinofili, fasiit ve "Groove" ișareti ile karakterize nadir görülen bir durumdur. Periferal kanda eozinofili ve özellikle ekstremitelerde skleroderma benzeri deri endurasyonları bu hastalığın karakteristik özellikleridir. Sistemik organlar genellikle etkilenmemiștir. Bu yazıda, uzun süre tanı konamayan ve kas biyopsisi sonrası eozinofilik fasit tanısı koyduğumuz 35 yașındaki erkek olgunun klinik özellikleri ve hastalık hakkında yaptığımız literatür taramasının sonuçları sunulmuștur. (Turk J Rheumatol 2010; 25: 208-13)

Anahtar sözcükler: Eozinofilik fasiit, groove ișareti

Alındığı Tarih: 05.11.2008

Kabul Tarihi: 05.12.2008

\section{Introduction}

Eosinophilic fasciitis (EF) is a rare inflammatory disease of unknown etiology. This disease presents itself, just like scleroderma, with skin and connective tissue indurations in the extremities. It is usually seen in young males, rarely in elderly women and sporadically in children (1).

In some of the patients with EF, Borrelia afzelii antigen (2) and IgG antibody against Borrelia burgdorferi were found to be positive (3). Furthermore, nutrition with denatured oil (4) and predominantly L-tryptophan (5) and long-term use of lansoprazole (6) have been postulated to induce EF. Some of the cases are seen following bone marrow transplantation, and EF can also be seen in cases with Hashimoto thyroiditis and aplastic anemia, which bring into mind an autoimmune etiology (7).

Clinical signs of this disease have been reported as swelling, indurations and skin thickening in the legs and arms. During the course of the disease, there is edema in the extremities evolving into woody indurations characterized by orange-colored hyperpigmentation and skin tenseness. Typically the "groove sign" can be seen in the extremities. Some cases of localized morphea, defined as localized inflammation in the reticular dermis and superficial panniculus, have been reported. Synovitis and contractures can accompany the disease. Some patients also have signs such as muscle weakness, pain and rigidity in the extremities. EF shares similarities with many diseases; therefore, diagnosis is usually delayed and confused (8).

In this report, we aimed to present the clinical signs of an EF case with substantial limitation in extremity function.

\section{Case Presentation}

A 35-year-old male patient was referred to our polyclinic with complaints of rigidity and movement 
restriction in his arms and legs. These complaints had started four months ago with swelling in the dorsum of both hands and feet. In two months, the swelling had transformed to joint rigidity and movement restriction. The patient described that this muscle rigidity had gradually spread from the hands to the shoulders and from the feet to the hips. Personal history of the patient revealed cigarette smoking, 2-3 packets/day. Family history was negative for any allergic or rheumatic diseases. He had no known exposure to polyvinylchloride or L-tryptophan.

During examination, no rash was found on inspection. Systemic examination revealed blood pressure of 120/80 $\mathrm{mmHg}$, pulse of 80 beats/min, respiration of $20 / \mathrm{min}$, and a body temperature of $36.2^{\circ} \mathrm{C}$. Examination of the musculoskeletal system showed sclerotic, thickened skin on legs and upper extremities. A groove sign was found on the right forearm (Figure 1). Neck and shoulder movements were moderately restricted and painless. Left elbow joint movement ranges were between 30-130 degrees. A 20 degree bilateral dorsiflexion was noted in the wrist joint. Bilateral metacarpophalangeal and proximal interphalangeal joints of the fingers had a flexion-extension movement range of 30 degrees. Moderate restriction was found in low back and hip motions. Both ankles were fixed at 90 degrees dorsiflexion. There was no sign of arthritis in the joints, and neurological examination of the patient was normal.

Laboratory tests revealed total peripheral blood leukocyte count of 11.000 with eosinophilia of $26.1 \%$ $(n=1-3 \%)$. Peripheral blood smear showed eosinophilic predominance as well. Liver function tests were normal, and hepatitis markers were negative. Erythrocyte sedimentation rate (ESR) was $77 \mathrm{~mm} /$ hour and C-reactive protein (CRP) level $51 \mathrm{mg} / \mathrm{dl}$. Rheumatoid factor and antinuclear antibodies (ANA) as well as salmonella and brucella agglutination tests were negative. Hypergammaglobulinemia was found in protein electrophoresis. The patient's tumor markers and thyroid function tests were within normal limits. No pathology was found in the microscopic and macroscopic examination of stool. Peripheral IgE level was within normal limits.

There was no pathologic sign in the lung X-rays, electrocardiographic examinations, abdominal ultrasonographic examination or in the electromyographic examinations of the upper and lower extremities.

In order to clarify peripheral eosinophilia and muscle rigidity, a subcutaneous and muscle biopsy was obtained from the calf. The histopathologic evaluation of the biopsy samples from the fascia and superficial striated muscle revealed an inflammatory infiltration comprising scarce eosinophilia, but a predominance of mononuclear cells and fibrosis in fascial soft tissue. Superficial spread of the infiltration into the muscle tissue was observed (Figure 2). These findings were reported as concordant with EF.
He was treated with fluocortolone $40 \mathrm{mg}$ daily for two months, with no clinical benefit. Therefore, methotrexate $(0.3 \mathrm{mg} / \mathrm{kg} /$ week $)$ was added to fluocortolone treatment. With the aim of rehabilitation, stretching exercises were performed on the restricted joints. The patient was examined three months later and healing was observed in the rigidity of the upper and lower extremities, and joint movement range was almost complete. ESR and CRP levels were normal and there was no peripheral eosinophilia.

\section{Discussion}

Eosinophilic fasciitis (EF) is a rare disease, first identified in 1974 by Shulman (1). Despite the lack of studies on its incidence, we have screened a total of 309 studies on EF published in English in PubMed-MEDLINE from 1974 to the present. Among these publications, there were 223 cases diagnosed as EF. Of these, we could

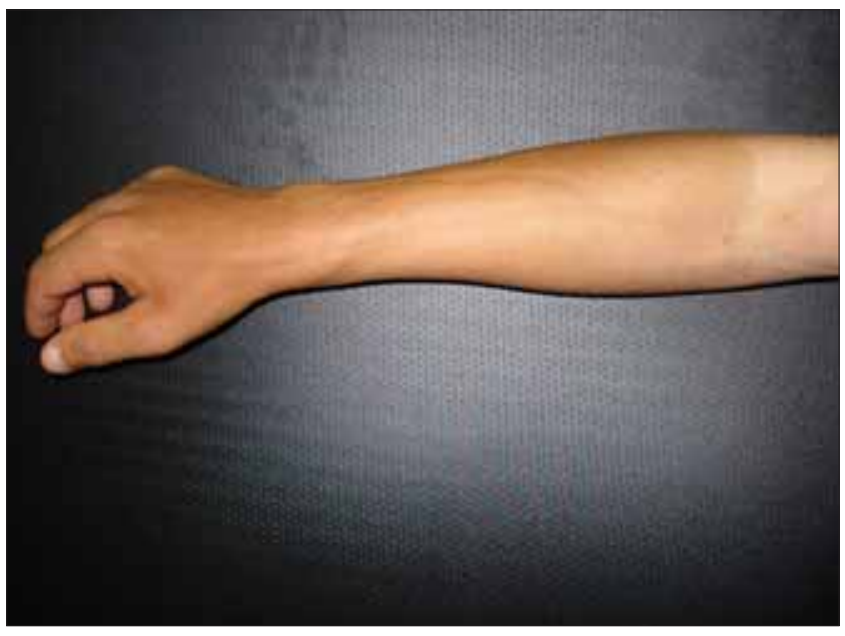

Figure 1. Groove sign on the right forearm

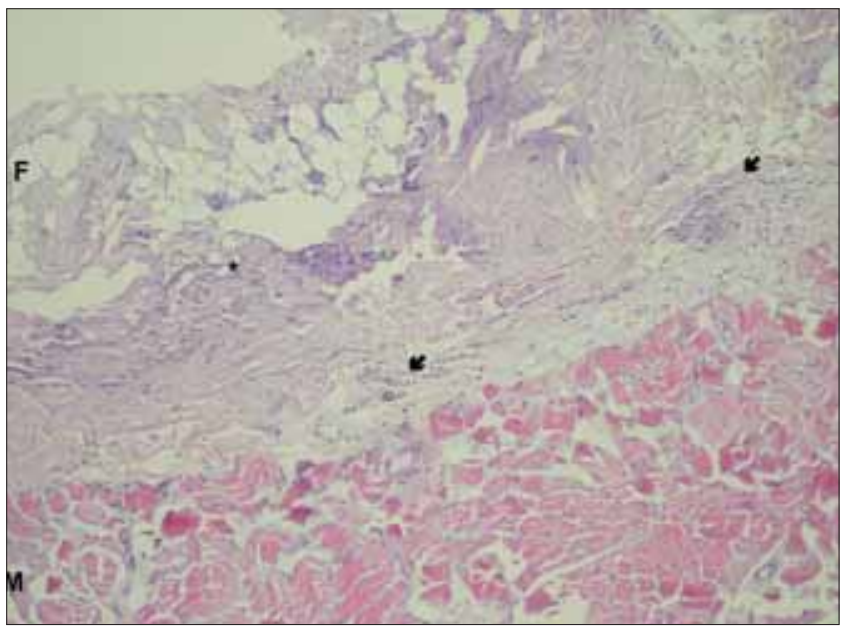

Figure 2. Inflammatory infiltration (arrow) with predominance of mononuclear cells and fibrosis (star) in fascial soft tissue (hematoxylin-eosin x200) 
Table 1. Demographic and clinical characteristics of eosinophilic fasciitis cases in the literature $(n=93)$

Age [year; mean (SS) ]

Min-max

$44.9(17.7)$

6-80

Sex (F/M)

$58 / 35$

Hypergammaglobulinemia $n(\%)$

Yes

$42(45.2)$

$22(23.7)$

Not reported

29 (31.2)

Elevated lgE level n (\%)

Yes
No
Not reported

$2(2.2)$

$7(7.5)$

$84(90.3)$

Peripheral blood eosinophilia $n$ (\%)

Yes

No

$77(82.8)$

$6(6.5)$

$10(10.8)$

Positive ANA n (\%)

Yes

15 (16.1)

$46(49.5)$

Not reported

32 (34.4)

Positive Scl-70 n (\%)

Yes

$2(2.2)$

$10(10.8)$

$81(87.1)$

Positive Borrelia burgdorferi antibody $\mathrm{n}(\%)$

Yes

$15(16.1)$

$10(10.8)$

Not reported

68 (73.1)

Treatment $\mathrm{n}(\%)$

Prednisolone and methotrexate

$10(10.8)$

Cyclosporin

OH-chloroquine

Azathioprine and methylprednisolone

$2(2.2)$

$3(3.3)$

$2(2.2)$

$3(3.2)$

$1(1.1)$

Prednisolone and cyclophosphamide

Prednisolone

Dexamethasone

$\mathrm{OH}$-chloroquine and methotrexate

Prednisolone and $\mathrm{OH}$-chloroquine

$43(46.2)$

$1(1.1)$

$1(1.1)$

1 (1.1)

$1(1.1)$

$1(1.1)$

Cyclosporin and methotrexate

$1(1.1)$

$1(1.1)$

PUVA and prednisolone

$5(5.4)$

$1(1.1)$

Prednisolone and cimetidine and cyclosporin

$1(1.1)$

5 (5.4)

Dexamethasone and pamidronate

Prednisolone and $\mathrm{D}$ penicillamine

1 (1.1)

$1(1.1)$

Methylprednisolone

$1(1.1)$

$1(1.1)$

D-penicillamine

$1(1.1)$

$1(1.1)$

$\mathrm{OH}$-chloroquine and prednisolone and cimetidine

$1(1.1)$

Penicillamine and azathioprine

Indomethacin

$1(1.1)$

Response to treatment $\mathrm{n}(\%)$

Deflazacort

No

$8(8.6)$

F: Female, M: Male, ANA: Anti-nuclear antibody 
reach only 93 cases with full text, and the clinical characteristics of these cases are given in Table 1 (8-65).

Cutaneous manifestations of EF have been described as progressive, with the earliest stage being edema of the extremities, followed by peau d'orange with hyperpigmentation, and finally induration (9). EF manifests itself with pain, edema, movement restriction, and skin thickening in the joints of the hands and feet. In some cases, these symptoms not only appear in the hands and the feet but can also comprise the extremities and the whole body. Rarely, conditions like splenomegaly, reactive hepatitis, esophageal dysmotility, peripheral neuropathy, autoimmune thyroiditis, hemolytic anemia, aplastic anemia, and thrombocytopenia can accompany the disease (9). In our case, there was movement restriction in the upper and lower extremities and thickening of the skin. The groove sign was seen on the right forearm. Based on our evaluation, there was no sign suggesting any systemic involvement.

Eosinophilic fasciitis can be seen along with other diseases. It has been reported along with collagen tissue diseases such as systemic sclerosis, Sjögren's syndrome, antiphospholipid syndrome, and systemic lupus erythematosus (10). Furthermore, EF has been reported as a paraneoplastic syndrome in some types of cancer such as colorectal carcinoma (11). In our case, there was no evidence of collagen tissue disease or cancer.

Laboratory findings of our patient revealed peripheral eosinophilia and IgE values within normal limits. Similar to our case's results, four of the five cases reported by Bobrowska-Snarska et al. (12) had normal IgE levels, and peripheral eosinophilia was reported in three of the five cases. Shulman (1) reported that hypergammaglobulinemia can be seen in these patients. Hypergammaglobulinemia was also observed in the protein electrophoresis of our case. In the 93 cases we evaluated, $45.2 \%$ had hypergammaglobulinemia and $82.8 \%$ had peripheral blood eosinophilia.

Muscle biopsy taken from the completely thickened skin area is the gold standard for diagnosis of EF. While there is eosinophilic and lymphocytic infiltration in the fascia, thickening due to the dense accumulation of collagen in the dermis is a typical pathological biopsy finding (9). Subcutaneous and muscle biopsy of our case also revealed inflammatory infiltration with eosinophilia and mostly a predominance of mononuclear cells as well as fibrosis in the fascial soft tissue.

Currently, there is no known effective treatment for EF. The best results have been observed with corticosteroid treatment. In cases resistant to corticosteroids, hydroxychloroquine, azathioprine (66) and methotrexate have been used (67). In some other studies, favorable results were obtained with cyclophosphamide, cyclosporine $\mathrm{A}$ and antithymocyte globulin application $(13,68,69)$. Weaker effects have been reported for colchicine and D-penicillamine (67). Interestingly, good results in treatments with histamine receptor antagonists (cetirizine and cimetidine) have been observed as well (70). Favorable results were also obtained in some cases from UV-A photochemotherapy and psoralen treatment (14). In some other cases, dramatic improvements in clinical findings were observed with hydroxychloroquine treatment (15). On the other hand, in the treatment results of a series of 12 cases, Bischoff et al. (9) emphasized that 13 months of combination therapy with hydroxychloroquine and corticosteroids had no healing effect at all. Fluocortolone at a dose of $40 \mathrm{mg}$ daily for two months was not effective in our case. Therefore, methotrexate $(0.3 \mathrm{mg} / \mathrm{kg} /$ week $)$ was added to the corticosteroid treatment. Clinical improvement was observed in a short period of combination therapy with corticosteroid and methotrexate. There are several studies reporting clinical improvement with corticosteroid and methotrexate combination therapy, similar to the situation in our case $(16,17)$. In 93 cases we evaluated from the literature, the treatment consisted mostly of prednisolone $(46.2 \%)$ and prednisolone-methotrexate combination therapies $(10.8 \%)$.

Most of the patients with EF are diagnosed as scleroderma due to skin indurations and fibrotic changes in tissues. Typically, in cases with EF, there are sensitive edematous and erythematous lesions in the extremities, with sudden onset. On the other hand, scleroderma is an insidious and slowly progressing disease. In contrast to scleroderma, sclerodactyly, Raynaud's phenomenon and visceral organ involvement are uncommon in EF patients. Different etiologic features and characteristics and different skin histologies differentiate these two diseases. EF can be differentiated from other diseases with capillary microscopy. Muscle weakness can be seen in cases with EF and can be confused with eosinophilic myalgia syndrome and myopathies. In cases with eosinophilic myalgia, pulmonary, cardiac, gastrointestinal, and neurologic signs are more acute and intense. In addition, increasing aldolase level, a muscle enzyme, is observed, differing from EF. The frequent confusion of EF with these diseases results in a delayed diagnosis (18-20). In our case as well, scleroderma was the suspected diagnosis, and EF was diagnosed through clinical findings and biopsy. However, aldolase levels could not be measured in our case.

In conclusion, the diagnosis of EF disease with routine clinical observation can be overlooked and therefore delayed. Good knowledge of the clinical features and early treatment can slow down the disease progression, which is substantially important regarding improvement in activities of daily life.

\section{Conflict of Interest}

No conflict of interest declared by the authors. 


\section{References}

1. Shulman LE. Diffuse fasciitis with hypergammaglobulinemia and eosinophilia: a new syndrome? J Rheumatol 1984;11: 569-70.

2. Kikuchi O, Murai H, Ikezoe K, Kawajiri M, Ohyagi Y, Isogai E, et al. Eosinophilic fasciitis associated with Borrelia afzelii infection. Rinsho Shinkeigaku 2004; 44: 299-302.

3. Belot $\mathrm{V}$, Mulleman $\mathrm{D}$, Perrinaud A, Abdallah-Lotf $\mathrm{M}$, Machet MC, Machet L. Eosinophilic fasciitis associated with Borrelia burgdorferi infection. Ann Dermatol Venereol 2007; 134: 673-7.

4. Diaz-Perez JL, Zubizarreta J, Gardeazabal J, Goday J. Familial eosinophilic fascitis induced by toxic oil. Med Cutan Ibero Lat Am 1988; 16: 51-8.

5. Smith JD, Chang KL, Gums JG. Possible lansoprazole-induced eosinophilic syndrome. Ann Pharmacother 1998; 32: 196200.

6. Lucena Marotta F, Sanz Moreno J, Herrera Serrano L, López Alvarez J, Alvarez de Buergo, Ballester M. Eosinophilic fasciitis: its relationship with L-tryptophan ingestion. An Med Interna 1995; 12: 337-9.

7. Hur JW, Lee HS, Uhm WS, Jun JB, Bae SC, Park CK, et al. Eosinophilic fasciitis associated with autoimmune thyroiditis. Korean J Intern Med 2005; 20: 180-2.

8. Endo $Y$, Tamura A, Matsushima $Y$, Iwasaki T, Hasegawa $M$, Nagai $Y$, et al. Eosinophilic fasciitis: report of two cases and a systematic review of the literature dealing with clinical variables that predict outcome. Clin Rheumatol 2007; 26: 1445-51.

9. Bischoff L, Derk CT. Eosinophilic fasciitis: demographics, disease pattern and response to treatment: report of 12 cases and review of the literature. Int J Dermatol 2008; 47: 29-35.

10. Kitamura $Y$, Hatamochi A, Hamasaki Y, Ikeda H, Yamazaki S. Association between eosinophilic fasciitis and systemic lupus erythematosus. J Dermatol 2007; 34: 150-2.

11. Philpott $H$, Hissaria $P$, Warrren $L$, Singhal $N$, Brown $M$, Proudman S, et al. Eosinophilic fasciitis as a paraneoplastic phenomenon associated with metastatic colorectal carcinoma. Australas J Dermatol 2008; 49: 27-9.

12. Bobrowska-Snarska D, Ostanek L, Brzosko M. Fasciitis eosinophilica: personal observations and a review of the literature. Pol Arch Med Wewn 2007; 117: 64-71.

13. Bukiej A, Dropinski J, Dyduch G, Szczeklik A. Eosinophilic fasciitis successfully treated with cyclosporine. Clin Rheumatol 2005; 24: 634-6.

14. Romano C, Rubegni P, De Aloe G, Stanghellini E, D'Ascenzo $\mathrm{G}$, Andreassi L, et al. Extracorporeal photochemotherapy in the treatment of eosinophilic fasciitis. J Eur Acad Dermatol Venereol 2003; 7: 10-3.

15. Dybowski F, Neuen-Jacob E, Braun J. Eosinophilic fasciitis and myositis: use of imaging modalities for diagnosis and monitoring. Ann Rheum Dis 2008; 67: 572-4.

16. Ortega-Loayza AG, Merritt BG, Groben PA, Morrell DS. Eosinophilic fasciitis in a female child. J Am Acad Dermatol 2008; 58 (5 Suppl 1): 72-4.

17. Serrano-Grau P, Mascaró-Galy JM, Iranzo P. Eosinophilic fasciitis after taking simvastatin. Actas Dermosifiliogr 2008; 99: 420-1.

18. Herson S, Brechignac S, Piette JC, Mouthon JM, Coutellier A, Bletry $\mathrm{O}$, et al. Capillary microscopy during eosinophilic fasciitis in 15 patients: distinction from systemic scleroderma. Am J Med 1990; 88: 598-600.
19. Smith LC, Cox NH. Dapsone treatment for eosinophilic fasciitis. Arch Dermatol 2008; 144: 845-7.

20. Horacek E, Sator PG, Gschnait F. 'Venous furrowing': a clue to the diagnosis of eosinophilic fasciitis. A case of eosinophilic fasciitis ultimately treated with oral PUVA therapy. Dermatology 2007; 215: 89-90.

21. Arce-Salinas CA, Pasquel-Garcia Velarde $P$, Villaseñor-Ovies $P$, Gonzalez-Toledo R. Isolated chronic severe neutropenia in eosinophilic fasciitis. Failure of response to granulocyte colony-stimulating factor. Clin Exp Rheumatol 2007; 25: 118.

22. Sugimoto $T$, Nitta $N$, Kashiwagi $A$. Usefulness of magnetic resonance imaging in eosinophilic fasciitis. Rheumatol Int 2007; 27: 791-2.

23. Plastiras SC, Pikazis D. Eosinophilic fasciitis in a patient with psoriasis: an unusual association. Clin Exp Rheumatol 2006; 24: 608.

24. Antic M, Lautenschlager $\mathrm{S}$, Itin $\mathrm{PH}$. Eosinophilic fasciitis 30 years after - what do we really know? Report of 11 patients and review of the literature. Dermatology 2006; 213: 93-101.

25. Antón E. Failure to demonstrate Borrelia burgdorferi-specific DNA in lesions of eosinophilic fasciitis. Histopathology 2006; 49: 88-90.

26. Pillen $S$, van Engelen $B$, van den Hoogen $F$, Fiselier $T$, van der Vossen P, Drost G. Eosinophilic fasciitis in a child mimicking a myopathy. Neuromuscul Disord 2006; 16: 144-8.

27. Minciullo PL, Morabito F, Mandaglio R, lacopino P, Gangemi $S$. Eosinophilic fasciitis associated with autoimmune phenomena after bone marrow transplantation: report of two cases. Clin Rheumatol 2006; 25: 80-2.

28. Suresh E, Doherty V, Schofield O, Goddard C, Dhillon V. Eosinophilic fasciitis and eosinophilic colitis: a rare association. Rheumatology (Oxford) 2005; 44: 411-3.

29. Roca B, Bennasar MA, Pitarch A. Miliary tuberculosis in a patient with eosinophilic fasciitis. South Med J 2005; 98: 107-10.

30. Ustun C, Ho G Jr. Eosinophilic fasciitis after allogeneic stem cell transplantation: a case report and review of the literature. Leuk Lymphoma 2004; 45: 1707-9.

31. Chan V, Soans B, Mathers D. Ultrasound and magnetic resonance imaging features in a patient with eosinophilic fasciitis. Australas Radiol 2004; 48: 414-7.

32. Imai T, Saitoh M, Matsumoto H. Eosinophilic fasciitis: MRI evaluation. Neurology 2003; 61: 416.

33. Jacob SE, Lodha R, Cohen JJ, Romanelli P, Kirsner RS. Paraneoplastic eosinophilic fasciitis: a case report. Rheumatol Int 2003; 23: 262-4.

34. Liou CH, Huang GS, Taylor JA, Juan CJ, Gao HW, Chen CY. Eosinophilic fasciitis in a military recruit: MRI evaluation with clinical correlation. Skeletal Radiol 2003; 32: 52-7.

35. Khanna D, Verity A, Grossman JM. Eosinophilic fasciitis with multiple myeloma: a new haematological association. Ann Rheum Dis 2002; 61: 1111-2.

36. Huppke P, Wilken B, Brockmann K, Sattler B, Hanefeld F. Eosinophilic fasciitis leading to painless contractures. Eur J Pediatr 2002; 161: 528-30.

37. Costenbader KH, Kieval RI, Anderson RJ. Eosinophilic fasciitis presenting as pitting edema of the extremities. Am J Med 2001; 111: 318-20.

38. Choquet-Kastylevsky G, Kanitakis J, Dumas V, Descotes J, Faure M, Claudy A. Eosinophilic fasciitis and simvastatin. Arch Intern Med 2001; 161: 1456-7. 
39. Vannucci P, Gaeta P, Riccioni N. Association of eosinophilic fasciitis and epileptic seizure. Clin Rheumatol 2001; 20: 223-4.

40. Huemer M, Seeber A, Huemer C. Scleroderma-like syndrome in a child: eosinophilic fasciitis or scleredema adultorum? Eur J Pediatr 2000; 159: 520-2.

41. Kim H, Kim MO, Ahn MJ, Lee YY, Jung TJ, Choi IY, et al. Eosinophilic fasciitis preceding relapse of peripheral T-cell lymphoma. J Korean Med Sci 2000; 15: 346-50.

42. Yamanishi $Y$, Ishioka S, Yamakido M. Complete remission of relapsing eosinophilic fasciitis associated with bronchial asthma following regular steroid inhalation. Rheumatology (Oxford) 2000; 39: 339-40.

43. Killen JW, Swift GL, White RJ. Eosinophilic fasciitis with pulmonary and pleural involvement. Postgrad Med J 2000; 76: 36-7.

44. Naschitz JE, Misselevich I, Rosner I, Yeshurun D, Weiner $P_{\text {, }}$ Amar $\mathrm{M}$, et al. Lymph-node-based malignant lymphoma and reactive lymphadenopathy in eosinophilic fasciitis. Am J Med Sci 1999; 318: 343-9.

45. Moriguchi M, Terai C, Kuroki S, Tanaka E, Someya N, Tsunoda $Y$, et al. Eosinophilic fasciitis complicated with peripheral polyneuropathy. Intern Med 1998; 37: 417-20.

46. Cetkovský P, Koza V, Cetkovská P, Svojgrová M. Successful treatment of severe Shulman's syndrome by allogeneic bone marrow transplantation. Bone Marrow Transplant 1998; 21: 637-9.

47. Flamen $P$, Dierickx L, Everaert $H$, Reychler R, Bruyland $M$, Franken PR, et al. Fascial Tc-99m MDP uptake in eosinophilic fasciitis as demonstrated by SPECT. Clin Nucl Med 1997; 22: 844-6.

48. Kato $Y$, Naito $Y$, Narita $Y$, Kuzuhara S. D-penicillamineinduced myasthenia gravis in a case of eosinophilic fasciitis. J Neurol Sci 1997; 146: 85-6.

49. Nishiya K, Tanimoto N, Hashimoto K, Hashizume M, Tominaga A. Serum and synovial fluid levels of interleukin-5 in a patient with eosinophilic fasciitis. Ann Rheum Dis 1996; 55: 935-6.

50. de la Cruz-Alvarez J, Allegue F, Oliver J. Acquired ichthyosis associated with eosinophilic fasciitis. J Am Acad Dermatol 1996; 34: 1079-80.

51. Rosenfeld K, Stodell MA. Eosinophilic fasciitis in a father and son. Ann Rheum Dis 1994; 53: 281.

52. Wright GD, Thornton C, Keegan DA, Bell AL. Eosinophilic fasciitis presenting as psoriatic arthropathy. Ulster Med J 1992; 61: 112-25.

53. Chalker RB, Dickey BF, Rosenthal NC, Simms RW. Extrapulmonary thoracic restriction (hidebound chest) complicating eosinophilic fasciitis. Chest 1991; 10: 1453-5.
54. Ching DW, Petrie JP. Childhood eosinophilic fasciitis presenting as inflammatory polyarthritis and associated with selective IgA deficiency. Ann Rheum Dis 1991; 50: 647-8.

55. Hamilton ME. Eosinophilic fasciitis associated with L-tryptophan ingestion. Ann Rheum Dis 1991; 50: 55-6.

56. Vengrove MA, Adelizzi RA. Eosinophilic fasciitis. J Am Osteopath Assoc 1986; 86: 508-11.

57. Jones HR Jr, Beetham WP Jr, Silverman ML, Margles SW. Eosinophilic fasciitis and the carpal tunnel syndrome. J Neurol Neurosurg Psychiatry 1986; 49: 324-7.

58. Bertken R, Shaller D. Chronic progressive eosinophilic fasciitis: report of a 20 -year failure to attain remission. Ann Rheum Dis 1983; 42: 103-5.

59. Griffin AJ. Eosinophilic fasciitis with megakaryocyte aplasia. J R Soc Med 1979; 72: 779-81.

60. Bennett RM, Herron A, Keogh L. Eosinophilic fasciitis. Case report and review of the literature. Ann Rheum Dis 1977; 36: 354-9.

61. Stubbs SL, Hughes GR. Eosinophilic fasciitis. Br Med J 1977; 1: 948-9.

62. al-Shaikh A, Freeman C, Avruch L, McKendry RJ. Use of magnetic resonance imaging in diagnosing eosinophilic fasciitis. Report of two cases. Arthritis Rheum 1994; 37: 1602-8.

63. Govalkar RM. Localized eosinophilic fasciitis. Ann Saudi Med 1995; 15: 636-9.

64. Baffoni L, Frisoni M, Maccaferri M, Ferri S. Systemic lupus erythematosus and eosinophilic fasciitis: an unusual association. Clin Rheumatol 1995; 14: 591-2.

65. Yamane K, Ninomiya H, Shabana M, Kono I, Kabashima T, Sakurai $\mathrm{T}$, et al. Eosinophilic fasciitis with prominent immunologic abnormalities. Jpn J Med 1983; 22: 134-6.

66. Farrell AM, Ross JS, Bunker CB. Eosinophilic fasciitis associated with autoimmune thyroid disease and myelodysplasia treated with pulsed methylprednisolone and antihistamines. Br J Dermatol 1999; 140: 1185-7.

67. Pouplin S, Daragon A, Le Loet X. Treatment of eosinophilic fasciitis with methotrexate. J Rheumatol 1998; 25: 606-7.

68. Valencia IC, Chang A, Kirsner RS, Kerdel FA. Eosinophilic fasciitis responsive to treatment with pulsed steroids and cyclosporine. Int J Dermatol 1999; 38: 369-72.

69. Bonnotte B, Chauffert B, Caillot D, Martin F, Lorcerie B. Successful treatment with antithymocyte globulin and cyclosporin A of a severe aplastic anaemia associated with an eosinophilic fasciitis. Br J Rheumatol 1998; 37: 1358-9.

70. Solomon G, Barland $P$, Rifkin H. Eosinophilic fasciitis responsive to cimetidine. Ann Intern Med 1982; 97: 547-9. 